\title{
Instrumentation of Character Implementation Research in Organizing the Educational Administration Santa Maria Senior High School Kabanjahe, Karo Districk
}

\author{
Yasinta Br Ginting, \\ Biner Ambarita, and Wanapri Pangaribuan \\ Administrasi Pendidikan-Universitas Negeri Medan \\ sintagintings@yahoo.co.id
}

2018

\begin{abstract}
This study aims to know the instrumentation of character implementation research in organizing the education administration at Santa Maria Senior High School Kabanjahe, focusing on the character implementation in organization curriculum administration and student administration at XI grade Semester 2 TP. 2017/ 2018. The specifically-answered Questions in this research are: (1) What character values are developed at Santa Maria High School Kabanjahe? (2) How are the character instrument in organizing curriculum administration and student administration developed at Santa Maria Senior High School Kabanjahe? The type of research is the descriptive qualitative research. The subject of the study is the principal, the vice principal, the form teacher of XI grade and the class representative of XI grade (the class monitor, the secretary and the treasurer of all classes of XI grade consisting of 15 people). The technique of data collecting is conducted through Observation, Documentation, Interview, and Triangulation. The data analysis used are Miles \& Huberman model, those are by: collecting data, presenting data, reducing data, verifying data and making conclusion. The data validity test is conducted through: credibility test, transferability test, dependability test and conformability test. As a result, the research is found that Santa Maria Senior High School Kabanjahe under the Foundation Setia Medan developed the character of SFD. There are three main values as the core values. Those are Spirit, Fraternity and Dina and there are nineteen derivative values of characters developed namely: Be always Happy, Diligent and enterprising, Energetic, Discipline, Joy, Lovely, friend, fraternity, Carrier Peaceful, Tolerant, Diligent Praying, Penance Continuous, Simple, Low Heart, Sincere, Dead body, Willing to Sacrifice, Honestly, without ulterior motives. Indicators developed from derivative values or character values comprise from indicators of one hundred and thirty nine of curriculum and ninety six indicators of forty three administration students.
\end{abstract}

Keywords: instrumentation assessment, implementation character and administration education.

\section{INTRODUCTION}

Education is the process of humanizing humans. Humanitarian values are the goal of education both in the formation of personality, skills and attitude towards obeying God's commands. Education in a broad sense is a process of personal formation in all aspects, namely the formation of physical and spiritual aspects. Education should remain integrated with the overall system of moral values and norms that are upheld by the community. Scientific attitudes that uphold rational truth and dedication to social life are important factors in education and character formation.

Ambarita and Nasrun state that education is in Indonesia In order to form an adult human being and an independent character, it has not succeeded. This failure occurred in almost all public and private educational institutions. Efforts can be made to form adult and independent people, among others by conducting character education program. Pangaribuan et al. say that lately the character of students has experienced degradation and must be immediately addressed okay However, so far various efforts have been made to build good character from students. Some of these efforts include the existence of Character Education, Religious Education, Pancasila Moral Education, Guidance and Con Services selling and enactment of the 2013 Curriculum which also emphasizes Character Education. Pen character training has been a concern since long ago, but character degradation still occurs. This is due to various factors. The most important factor But it is a factor of students, teachers, parents, friends, school environment, community and environment, reading books, social media and methods or models of character education itself. Character education needs to be a concern for all pen managers upbringing.

One school that pays attention to character education is Santa Maria Senior High School Kabanjahe. This school has tried to explore character values, formulate and socialize them to all teachers, employees and students. Based on the discussion with Waji, S.Pd Principal of Santa Maria Senior High School Kabanjahe stated that since the beginning of 2016 the process of formulating and socializing the Medan Setia Foundation character values had begun, Santa Maria Senior High School Kabanjahe was one of the schools under the Setia Medan Foundation. Principals, Deputy Principals and representatives of Teachers / Employees from each school managed by the Setia Medan Foundation with guidance from resource persons who are considered capable of starting the process of implementing the formulation process and character values developed by the Setia Medan Foundation which 
includes Santa High School Maria Kabanjahe Karo Regency. The school principal also explained that attention to character education in Santa Maria Senior High School Kabanjahe was also carried out by putting up posters of character values to SFD in each class and office in the form of pictures of mangos teen trees that were flowering and fruiting. The civilization of character values in Santa Maria Senior High School Kabanjahe was also carried out in the presence of "SFD Greetings". Every morning the teacher / teacher and sister who serves as picket welcomes the presence of students, teachers and employees at the school greetings by saying "Good Morning, Greetings SFD" in a typical shake hands.

Education administration according to Purwanto is the whole process of mobilization and integration of all things, both personnel, spiritual, and material related to the achievement of educational goals. Educational administration is the effort of the people involved in the process of achieving the goals of education that are integrated, organized and coordinated effectively, and all the material that is needed and existing is used efficiently. Dadang Sukandar in the Lecturer Team states that education administration as a science that discusses education from the point of view of the process of cooperation between humans in developing the potential of students through changes in attitudes in learning to achieve educational goals effectively and efficiently. Based on some of the opinions above it can be concluded that the administration of education is an activity of managing the elements that exist in education so that activities can be carried out effectively and efficiently.

The main functions of educational administration according to Purwanto are: (1) Planning (2) Organizing, (3) Coordinating, (4) Communication, (5) Supervision, (6) Personnel (7) Financing. Whereas according to Farikhah the administrative functions of education are: (1) Planning, (2) Organizational structure, (3) Communication and Coordination, (4) Supervision and Control, (5) Decision Making and Solution to problem.

Based on this opinion it can be concluded that the main functions of the administration of education are: planning, organizing, coordinating, communication, supervision, staffing, financing and decision making. The main functions of educational administration that are the focus of this research are: planning, organizing, coordinating, implementing and supervising.

Wiyani states that planning is the determination of a series of actions to achieve something desired. In connection with the definition of planning, Purwanto states that planning is the activities of thinking and choosing actions that are confess that the purpose and purpose are achieved. According to Fahrikhah planning is a series of activities that have been predetermined to achieve certain goals. Planning includes activities to formulate and define the Vision, Mission of the school.

Based on some of the opinions above, it can be concluded that planning is to determine a series of actions to be taken and how to do it so that the achievement of objectives can be effective and efficient. Formulating and establishing Vision,
Mission and Objectives included in a series of educational planning activities.

Purwanto states that organizations as one of the administrative functions of education can be said as activities to form and form relationships so as to realize business unity in achieving educational goals and objectives. right Organizing according to Wiyani is the overall activity of management in grouping people and assigning tasks, functions, authorities and responsibilities with the aim of creating activities that are efficient and effective in achieving the stated goals. While Farikhah states that in general organization is defined as giving the structure of people in a cooperative group which is intended to form a pattern of activities to lead to the achievement of common goals.

Based on the three opinions above it can be concluded that organizing is activities that aim to organize the pattern of cooperation of every human element in an organization to create activities that support the achievement of common goals that have been set.

Ushansyah states that the various tasks performed by many people require coordination of a leader. Good coordination avoids the possibility of unfair competition and confusion in action. Furthermore, Ushansyah stated that educational programs in schools are very complex, therefore coordination is needed that can bring people, material, thoughts, techniques, goals into harmonious and productive relationships in achieve goals. According to Santoadi coordination means that all elements (organs) function synergistically-collaboratively. Collaboration among various education staff will occur if communication between staff is going well and trusting each other. Conditions like this will be created if each person respects the duties, obligations and authority of each member.

Wiyani states that one of the functions of management is to carry out various activities in order to avoid chaos, dispute, emptiness of activities, by connecting, integrating and harmonizing subordinates' work so that there is direct cooperation in the effort to achieve common goals or organizational goals. Wiyani further stated that the effort that could be done to achieve the objectives included: (1) by giving instructions; (2) by giving orders; (3) holding meetings to provide explanations; (4) provide guidance or advice; (5) conducting coaching; and (5) if necessary to give a warning.

In connection with some of the opinions above it can be concluded that coordination is very important in achieving goals. Coordination can be understood as an activity to organize and unify understanding in carrying out activities so that all elements synergize in the pen goal achievement.

Wiyani states that the implementation is an activity to realize the plan to be a real action in order to achieve the goal effectively and efficiently, so that it will have value. Implementation can also be called implementation. Irrijal states that implementation is the program implementation process so that it can be run by all parties in the organization and the memo process motivation so that all parties can carry out their responsibilities with full awareness and high productivity. Based on these two opinions But it can be concluded that the implementation or implementation is an 
activity in the administration that aims to realize a program that has been prepared by involving all parties in the organization to carry out their duties and responsibilities with full awareness and high productivity so that they can reach their goals effectively and efficiently.

Understanding of supervision according to Wiyani is as an effort to observe systematically and continuously, record, provide explanations, instructions, coaching and rectify things that are not right, and correct mistakes, and are the key to success in the entire management process. Monitoring is often also called controlling. Pangaribuan states that controlling is the process of supervision and inspection and regulation by the authorities (owner of authority). The implementer of control is a person who has more authority and power to the personal or controlled system. Supervision is often also called supervision. According to Basri the term supervision comes from English, namely supervision, consisting of super words, meaning over or more and vision, meaning to look or watch. So supervision can be interpreted to see from above or supervision. The person who supervises is called a supervisor. Basri also states that the term supervisor can be formulated as a person who provides assistance, guidance, direction to teachers and / or other education personnel to improve teaching and learning activities in schools. According to Satori supervision is an effort to provide services to teachers, both individually and in groups in an effort to improve teaching. Academic supervision is a function aimed at quality assurance of learning carried out by the teacher. Based on the above opinion it can be concluded that supervision, control and supervision are assistance provided to teachers and other education personnel through professional guidance and direction so that teachers and education personnel are more optimal in carrying out their duties in order to improve the quality of education in schools.

According to Farikhah the curriculum is a tool to achieve the national education goals set out in the national education system law. The curriculum management includes planning, implementing activities up to evaluation of the implementation of the curriculum. Planning has been carried out by the ministry of education and culture and the authorities are the center of the curriculum and books under the auspices of the Research and Development Agency. Meanwhile, according to Purwanto the curriculum is a guide for teachers in carrying out their duties. In using the curriculum the teacher follows what is stated in it, has the right and obligation to also choose and add materials, sources or methods and implementation that is more in line with the development needs of the community, the school environment, and dispose of and reduce what is deemed inappropriate with the progress and needs of society and the State in general. In connection with the administration of the curriculum, the UPI Lecturer Team states that the autonomy given to educational institutions in managing the curriculum independently by prioritizing the needs and attainment of goals in the vision and mission of educational institutions does not neglect established national policies.
Based on these three opinions, it can be understood that the curriculum is a tool to achieve national education goals that have been established. The curriculum administration includes planning, implementing and evaluating curriculum. The curriculum that has been prepared by the government serves as a guideline for curriculum development in educational institutions or schools.

Ariska's research on student management at Lubuklinggau State High School 2 stated that (1) the school arranges student management planning in accordance with the development and needs of the school; (2) Mechanism of new student admission through standard procedures, namely: forming a new student admission committee, making announcements of new student admissions and meeting a new student admissions committee; (3) The selection process and student orientation activities are guided by the technical instructions given by the education office; (4) The grouping of new students is carried out according to the provisions and policies of the school which apply the principle of grouping students randomly; (5) The guidance of students and the provision of special services through Guidance and Counseling are also carried out by the school; (6) Activities in the form of monitoring the planning program up to the implementation program carried out by the school in accordance with the existing provisions and policies. Whereas according to Farikhah the administration of student affairs includes the management of student admission, management of Guidance and Counseling, management of Student Council and data management of students. The Lecturer Team the management of students is not limited to recording students' data, but includes broader aspects that can be operationally used to help smooth the growth and development of students through the process of education in schools. The scope of management of students according to the Lecturer Team: (1) Analysis of the needs of students; (2) Recruitment of students; (3) Selection of students; (4) Orientation; (5) Placement of students; (6) Development and development of students; (7) Recording and reporting; (8) Graduation and alumni. Special services that support student management include: BK services, library services, school canteen services, health services (UKS), school transportation services, and boarding services.

Based on the description above it can be concluded that students or students in schools must be managed properly. The management is called student administration. Student administration begins when students enter an institution until the student leaves an educational institution. Student management is related to the development and also data related to students, among others: management of new student admission and placement, student development and development, as well as recording and reporting student data.

According to Berkokwitz in Pangaribuan it was stated that the selection of a character education model that is in accordance with the characteristics of the students' subjects from the school determines success. The selection of character education models for a school should be adjusted to the conditions and conditions, especially in accordance with the school's vision and mission. Each school is possible to 
have a unique character development model, although it may have similarities with other schools. Based on this opinion it can be concluded that character development needs to be done in every school. Character values developed are adapted to the situation and conditions of the school such as the background of the school establishment, the spirit of the founder, and the vision and mission of the school.

\section{METHOD}

The research of method used is qualitative research with a qualitative descriptive approach. The selection of this approach is based on the consideration that what taken is data that describes the understanding of the Principal, Deputy Principal, and Class XI Guardian of the character values developed in the administration of education at Santa Maria Senior High School Kabanjahe in Karo Regency, which includes values character in: administrative planning of students and curriculum administration, organizing student administration and curriculum administration, coordinating student administration and curriculum administration, implementing student administration and curriculum administration and supervision of student administration and curriculum administration. This approach also aims to get depth and natural insight and interpretation of the meaning of phenomena and realities that arise in the field. Qualitative research emphasizes more on aspects of the process than just results. Qualitative research has a natural setting so it is descriptive naturalistic.

Data analysis used in this study is qualitative data analysis according to Milles and Huberman's model as cited by Sugiyono states that research data analysis has been carried out from the beginning of the activity until the end of the activity, with the hope of consistency in data analysis. Data analysis of this model is by dividing data analysis activities into several parts, namely: data collection, grouping according to variables, data reduction, data presentation, separating data outliers and drawing conclusions or verification of data.

\section{RESEARCH RESULTS AND DISCUSSION}

\section{Character Values developed at Santa Maria Senior High School Kabanjahe.}

Santa Maria Senior High School Kabanjahe, which is under the auspices of the Setia Medan Foundation since the 2015/2016 school year, has begun to explore the spirituality values of the work based on the spirit of the founder of the school, the Congregation of the Sisters of Franciscan Dina (SFD). The whole work of the Congregation of the Franciscan Sisters of Dina is lived by the SFD Spirituality values contained in three Main Values, namely: Spirit (S), Fraternity (F) and Dina (D).

Enthusiasm means always being happy, diligent, and active in carrying out each assigned work, with high discipline and great joy. Derivative values or character values of spirit, namely: (1) Always happy (happy, patient in difficulties) (2) energetic (resilient or unyielding), (3) diligent and diligent (responsible, hardworking and diligent at work), (4) Discipline (orderly, orderly and obedient), (5) Joyful (able to be grateful and grateful).

Fraternity means prioritizing and exalting the destitute and all beings that are loving, friendly, brothers, and become peacemakers wherever they are. Derivative values or character values of the Fraternity, namely: (1) Love (being a supporter of brotherhood), (2) Friendly (smile, greetings), (3) Brothers (helping each other, serving, cooperating), (4) Carrier Peace (fair / impartial, prioritizing togetherness and unity, not exaggerating problems, creating a harmonious atmosphere), (5) Tolerant (respecting, accepting and open to differences in ethnicity, religion and class).

Dina means that with the spirit of prayer and repentance that continues to grow simple, humble, sincere, penitent, willing to sacrifice and selfless. Derivative value or character value from Dina, namely: (1) Diligent Pray (relying on God / Believing in Divine Organization), (2) Continuous Penance (self-renewal), (3) Simple (guacharo), (4) Humility (not arrogant / accepting all people as they are), (5) Sincere (not acting, "no shrimp behind the rock"), (6) Matiraga (dare to say enough / just fulfill what is needed / dare to apologize if wrong), (7) Willing to Sacrifice (generous, giving time and energy, defeating oneself), (8) Honest (saying true, transparent), (9) Selfless (not primarily due to reward, sincerity).

\section{Instrument of Character Implementation in Organizing Curriculum Administration and Student Development Developed at Santa Maria Senior High School Kabanjahe \\ The character indicators for SFD are 139 (one hundred thirty nine) which are carried out well according to class XI students as many as 128 (one hundred twenty eight), while those not implemented by 1 indicator and which are sometimes carried out by 10 indicators, can be seen in table - 1 below this.}

TABLE 1. Indicators of the Character of Students in Class XI Semester Two that Are Not Implemented and Sometimes Implemented

\begin{tabular}{|l|l|}
\hline NO & \multicolumn{1}{c|}{ INFORMATION } \\
\hline \multicolumn{2}{|c|}{ Indicators that are not implemented } \\
\hline 1. & Get used to morning exercise \\
\hline \multicolumn{2}{|c|}{ Sometimes Indicators Done } \\
\hline 1. & Maintain a healthy lifestyle \\
\hline 2. & Brotherhood correction \\
\hline 3. & Read and meditate on the Scriptures \\
\hline 4 & Lead morning devotions \\
\hline 5. & Able to reflect \\
\hline 6. & Receive the Sacrament of Penance \\
\hline 7. & Devotion \\
\hline 8. & Putting the interests of others first \\
\hline 9. & $\begin{array}{l}\text { Familiarize culture with the interests of } \\
\text { others }\end{array}$ \\
\hline 10 & Control emotions \\
\hline
\end{tabular}


The character indicators for SFD are 139 (one hundred thirty nine) which are carried out well according to Santa Maria Senior High School Kabanjahe teachers as many as 135 (one hundred thirty five), while the one that is not carried out by one indicator and which is sometimes carried out by 3 indicators, can see in table- 2 below.

TABLE 2. Indicator of the Character of Santa Maria Senior High School Kabanjahe Teachers Implemented and Sometimes Implemented

\begin{tabular}{|l|c|}
\hline NO & INFORMATION \\
\hline \multicolumn{2}{|c|}{ Indicators that are not implemented } \\
\hline 1. & Get used to morning exercise \\
\hline \multicolumn{2}{|c|}{$\begin{array}{c}\text { Sometimes Indicators } \\
\text { Done }\end{array}$} \\
\hline 1. & Brotherhood correction \\
\hline 2. & Putting the interests of others first \\
\hline 3. & Manage time well \\
\hline
\end{tabular}

Based on the description above it can be said that the character values to SFD have been well supported by all school residents, although there are still some character indicators that need special attention so that all character attributes can be implemented properly.

\section{CONCLUSIONS AND SUGGESTIONS}

\section{Conclusion}

Based on the results of research on Instrumentation Assessment of Character Implementation in Organizing Educational Administration of Santa Maria Senior High School Kabanjahe in Karo Regency It can be concluded: Character values developed at Santa Maria Senior High School Kabanjahe in Karo Regency are the character values of SFD's namely Spirit, Fraternity and Dina. The core value of Spirit consists of five (5) derivative values called the values of the spirit character, namely: always happy, diligent and active, energetic, disciplined and joyful. The core values of the Fraternity consist of five (5) derivative values called the Fraternity character values, namely: love, kindness, brotherhood, peacemaker and tolerance. Dina's core values consist of nine (9) derivative values called Dina character values, namely: diligently praying, repentance continuously, simple, humble, sincere, mortal, and willing to sacrifice, honest and without ulterior motives. The total number of character values developed in Santa Maria Senior High School Kabanjahe is nineteen (19) characters. According to class XI students, 128 indicators were carried out well, 10 indicators were sometimes implemented and 1 indicator was not implemented. Indicators that are well implemented according to Santa Maria Senior High School Kabanjahe teachers are 135 while 1 indicator is not implemented and sometimes 3 indicators are carried out.

\section{Suggestion}

Some suggestions can be formulated for parties:

a. For principals so that the values of SFD's character to be a priority in the management of education at Santa Maria Senior High School Kabanjahe.

b. For teachers who teach in Santa Maria Senior High School Kabanjahe in their duties as educators, they become role models in living the character values into SFD.

c. For teachers Guidance and Counseling so that character indicators that are not implemented and sometimes carried out become classical guidance material in Santa Maria Senior High School Kabanjahe.

d. For Medan Setia Foundation Chairman making policies related to teacher coaching and employees on a regular basis in the implementation of character values to SFD's.

e. For researchers for further research, this research is still in the field of curriculum administration and students are expected to develop into other fields that have not been examined in this study.

\section{REFERENCES}

[1] B. Ambarita and Nasrun. 2016. Management of Education and Quality Improvement. Bandung: Alfabeta.

[2] Ariska, Ria Sita. 2015. Student Management. University of Bengkulu Education Manager Journal Vol. 9 p. 828 - 835.

[3] Basri, Hasan. 2014. Principal Leadership . Bandung: Faithful Library

[4] Farikhah, Siti. 2015. Management of Educational Institutions Yogyakarta: Aswaja Pressindo

[5] Irrijal. 2017. Implementation of Integrated Quality Management at Madrasah Aliyah Negeri (MAN) 2 Medan Model.

[6] W. Pangaribuan, Rambe and Ambarita. 2012. Character Education in Higher Education (Concepts and Implementation). Medan: UNIMED PRESS

[7] Pangaribuan, Wanapri. 2017. Influence of Organizational Culture, Organizational Commitment, Communication and Effectiveness of Control Systems Performance Management To Performance. Dissertation. Education Management. State University. Field

[8] Purwanto, Ngalim. 2014. Administration and Supervision of Education . Bandung: Rosdakarya

[9] Santoadi, Fajar. 2010. Comprehensive Guidance and Counseling Management. Yoyakarta: Sanata Dharma

[10] Satori, Djam'an. 2016. Supervision and Quality Assurance of Education . Bandung: Alfabeta

[11] Sugiyono. 2014. Educational Research Methods. Bandung: Alfabeta

[12] Lecturer Team. 2016. Management Education . Bandung: Alfabeta

[13] Ushansyah. 2017. The Importance of School Administration for the Advancement of Education. Ittihad Journal Kopertais Region XI Kalimantan , Vol. 15, No. 27, Hal. 13-22.

[14] Wiyani, Novan Ardi. 2012. Management of Character Education, Concepts and its Implementation in School. Yogyakarta: Pedagogia 